\title{
Yield gap Analysis of Rapeseed- Mustard through Cluster Front Line Demonstrations in Darbhanga District of Bihar, India
}

\author{
Ram Prawesh Prasad ${ }^{1 *}$, D. Shekhar ${ }^{1}$, M. S. Kundu ${ }^{2}$, A. P. Rakesh ${ }^{1}$, \\ Amba Kumari ${ }^{1}$ and Chandan Kumar ${ }^{1}$ \\ ${ }^{1}$ Krishi VigyanKendra, Jale, Darbhanga(Bihar)-847302, India \\ ${ }^{2}$ Dr. Rajendra Prasad Central Agricultural University, Pusa, \\ Samastipur, Bihar-848125, India \\ *Corresponding author
}

\section{A B S T R A C T}

\begin{tabular}{|l|}
\hline Ke y w o r d s \\
Rapeseed -Mustard \\
CFLDs, \\
Technological gap, \\
Extension gap, \\
Technological gap, \\
B:C:R \\
\hline Article Info \\
\hline Accepted: \\
14 May 2020 \\
Available Online: \\
10 June 2020 \\
\hline
\end{tabular}

\section{Introduction}

Mustard is among the oldest recorded spices as seen in Sanskrit records dating back to about 3000 BC (Mehra, 1968) and was one of the first domesticated crops. Originally it was the condiment that was known as mustard and the word was derived from the Latin mustum. Must, the expressed juice of grapes or other fruits mixed with ground mustard seeds to
Mustard is among the oldest recorded spices as seen in Sanskrit records dating back to about 3000 BC (Mehra, 1968) and was one of the first domesticated crops .In India, the mustard rapeseed is the most important oil seed crop after groundnut accounting around 25 per cent of total oilseed production. It is one of the important oilseed crop of the Indo-gangetic plains. Indian mustard (Rai) cultivation has occupied about 85-90 per cent of total area under cultivation of mustard - rapeseed. The present study was carried out at KVK, Jale, Darbhanga Bihar to know the yield gaps between improved package and practices(IP) under Cluster Font Line Demonstrations(CFLDs) and farmers practices (FP) of rapeseed mustard. The study found, the yield of rapeseed mustard in improve practices (IP) under irrigated condition range from 14.04to15.67, where as in FP it range between9.8to $10.25 \mathrm{q} / \mathrm{ha}$. The percent increase in yield IP over FP was recorded in the range of 37.64 to 55.61. The extension gap and technological index were range between 3.84-5.5 q/ha and 30.20percent respectively. The trend of technological gap reflected to farmer cooperation in carrying out demonstrations with on ranging result in subsequent years. The cost benefit ratio was 2.49 and 2.83 under demonstration, while it was1.52to 2.0under control plots. By conducting Cluster Front Line Demonstrations (CFLDs) of proven technologies, yield potential of rapeseed- mustard crop should be enhanced to a great extend with increase in the income level of farming community. 
In India, the mustard - rapeseed is the most important oil seed crop after groundnut accounting around 25 per cent of total oilseed production. It is one of the important oilseed crop of the Indo-gangetic plains. Indian mustard (Rai) cultivation has occupied about 85-90 per cent of total area under cultivation of mustard - rapeseed.

Besides, the utilities of oil obtained from mustard-rapeseed, the seeds, sprouts, leaves, tender plants are also useful to human health, when they are consumed as spices and vegetables. They contain selenium, calcium, magnesium, iron, phosphorus, zinc, magnesium, manganese, etc. Several bioticabiotic and socio- economic constraints inhibits exploitation of the yield potential and these needs to be addressed.

Darbhanga district has the sizeable area under mustard cultivation but the productivity level is very low. The seasons for low productivity about newly released crop production technologies and their management practices in the farmer fields. Keeping the above point in view, the CFLDs on rapeseed-mustard using production improved technologies was conducted with the objective of showing the productive potential of the new production technologies under actual farm situation.

\section{Materials and Methods}

The present study was carried out the Krishi Vigyan Kendra, Jale Darbhanga, Bihar during rabi season from 2017-2018 to 2019-20 (Three consecutive years) in the farmers field in fifteen village viz. Jale, Jogiara, Garri, Sandohi, Belwara, Kamtaul, Ahiyari, Brahmpur, Sanahpur, Kolhanta, Godaepatti, Kamalpur, Bhachhi and Kushiyam of Darbhanga district of Bihar.

During the three year of study, an area of covered 0.4 ha.(one acre) under Cluster Front
Line Demonstration (CFLD) with active participation of farmers of different villages were conducted. Before conducting CFLD a list of farmers was prepared from group meeting and specific skill training was impaired to the selected farmers regarding different aspect of cultivation etc., were followed as suggested by Chaudhary.1999 and Venkatta Kumar et al., 2010.

Materials for present study with respect to CFLDs and farmers practices has been given in Table No.1.In case of local check plots, existing practices being used by farmers were followed. In general soils of area under study are sandy loam and medium fertility status.

In demonstration plots use quality seed of improved variety, timely weeding, need based application of pesticides used of balance fertilizers (using micro nutrient sulphur)and use of suitable fungicides is Carbendazin $35 \%$ WP for seed treatment as suggest by Chattopadhyay et al., (2003) was used as technical interventions. For the controlling of aphid (Lipaphidscrrysimi) Diamethoate 30 $\% \mathrm{EC}$ was used in demonstrated plots given in package and practices for the Zone I, Bihar region were emphasized and comparison has been made with the existing practices.

Visits of farmers, the district agriculture line department and extension functionaries was organized at demonstration plots to disseminate the massage at large scale. The demonstrated farmers were facilities by KVK scientists in performing field operation like sowing, spraying, weeding, harvesting etc. during the course of training and visits.

The necessary steps for selection of site and farmers layout of demonstrations etc., were followed as suggested by Chaudhary(1999). Traditional practices were mentioned in case of local checks. The data outputs were collected from both CFLD plots as well as 
control plots (farmers practices) and finally the extension gap, technology gap, technology index along with the benefit cast ratio(B:C:R) worked out (Sanui et al., 2000) as given below:

Technology gap $=$ Potential YieldDemonstration Yield.

Extension gap $=$ demonstration Yield Farmers yield.

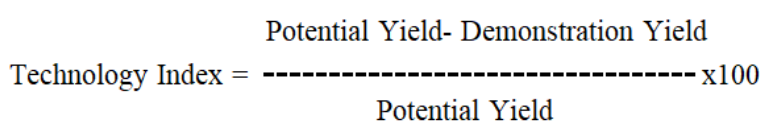

\section{Results and Discussion}

The result of 543 Cluster Front Line Demonstrations (CFLDs) conduct during 2017-18 to 2019-20 in 200ha area. On farmers field fifteen village of Darbhanga district indicated that the cultivation practices comprised under-CFLD viz- used of improved variety (RajendraSuflam\&RH0749),line sowing, balance used of fertilizers, sulphur, Zinc, weedicide, and control of mustard aphid through insecticides at economic threshold level, production on an average $49.62 \%$ more yield of mustard as compared to local practises $(10.12 \mathrm{q} / \mathrm{ha})$. The data of table 2.revwal that the yield of rapeseed- mustard fluctuated successively over the field of demonstrated plots. The maximum yield was recorded $15.67 \mathrm{q} /$ ha over local practices $(10.25 \mathrm{q} / \mathrm{ha})$. The increase in percentage of yield was range between $37.64 \%$ to $55.61 \%$ during four year study. The similar results of yield enhancement in rapeseed crop in front line demonstrations has been documented by Mitra and Samajdar (2010), in tarai zone of west Bengal. The results are also in conformity with the findings of Tiwari and Saxena (2001), Tiwari et al., (2003) Tomer et al., (2003), Singh et al., (2007) and Katare et al., (2011).

Table.1 Comprison between demonstration package and existing farmers practices under

\begin{tabular}{|c|c|c|}
\hline Particulars & $\begin{array}{c}\text { Rapeseed-Mustard Demonstration } \\
\text { package }\end{array}$ & Farmers practices \\
\hline Farming situation & Irrigated medium land & Irrigated medium land \\
\hline Variety & RajendraSuflam and & Local \\
\hline Time of sowing & 15 October to Last November & 15 November to 05 December \\
\hline Method of sowing & Line sowing & Broad casting \\
\hline Seed rate & $5 \mathrm{Kg} / \mathrm{ha}$. & 6-7 Kg/ha. \\
\hline Fertilizes dose & $\begin{array}{l}\left(60 \mathrm{kgN}, 40 \mathrm{kgP}_{2} \mathrm{O}_{5}: 40 \mathrm{kgK}_{2} \mathrm{O}, 30 \mathrm{~kg}\right. \\
\text { Sulphur, } 20 \mathrm{~kg} \text { Boron and } 20 \mathrm{~kg} \\
\text { Zinc. }(21 \%)\end{array}$ & $120 \mathrm{kgN}, 80 \mathrm{kgP}_{2} \mathrm{O}_{5}$. \\
\hline Plant protection & $\begin{array}{l}\text { Need based used of Carbendazim } \\
12 \%+\text { Mancozeb } 63 \% \text { WP(Saaf) for } \\
\text { fungal disease and Imidachlopride } \\
17.8 \text { SL /Dimethoate } 30 \% \text { EC to } \\
\text { protect the crop against aphid. }\end{array}$ & Nil. \\
\hline Weed management & $\begin{array}{l}\text { Pendamathilian @ } 0.3 \mathrm{~kg} \text { a.i } / \text { ha pre } \\
\text { emergence followed by one hand } \\
\text { weeding at } 20 \text { DAS. }\end{array}$ & $\begin{array}{l}\text { Two hand weeding at } 20 \text { and } \\
\text { 35DAS. }\end{array}$ \\
\hline
\end{tabular}
Rapeseed - Mustard practices 
Table.2 Productivity, technology gaps, extension gaps, technology index and benefit cost ratio of Rapeseed -Mustard (Rajendrasuflam \& RH-0749) grown under CFLDs and existing package of practices

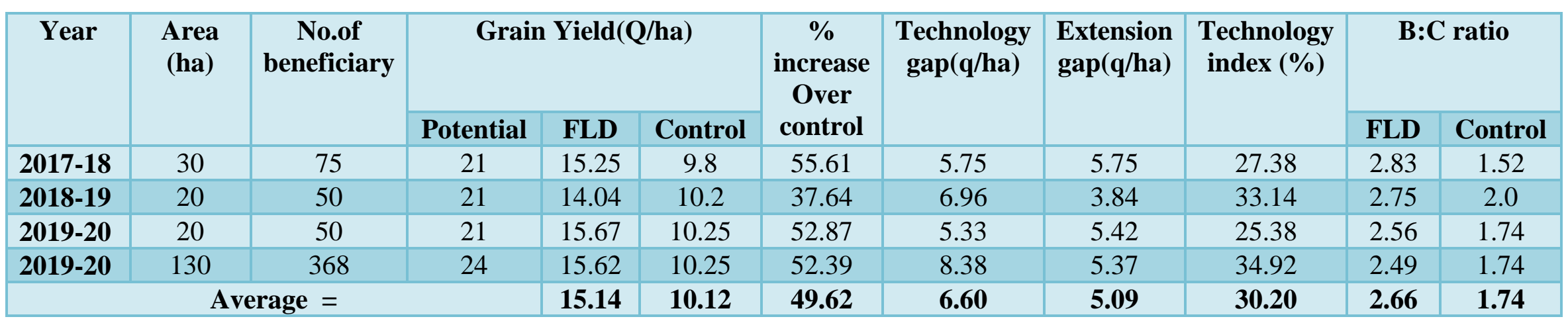

Table.3 Yield parameters under demonstration package and existing farmer's practices

\begin{tabular}{|l|c|c|}
\hline Yield parameters & Package of demonstration & Existing farmers practices \\
\hline No.of siliqua/plant & $162.33-139.67$ & $81.67-94.33$ \\
\hline No.of seeds/ siliqua & $9.33-11.67$ & $7.67-8.00$ \\
\hline Test weight (g) & $4.14-5.27$ & $3.60-4.22$ \\
\hline
\end{tabular}


The results indicated that the Front line demonstrations has given a good impact on the farming community of this district as they were motivated by the improved agricultural technologies used in the Front line demonstrations. The result clearly indicates the positive effect of CFLDs over the existing practices toward in enhancing the yield of rapeseed- mustard in Dabhanga area, with its positive effect on yield attribute (Table 3). Benefit Cost ratio was recorded higher under demonstration against control of all the year of study. These results were also supported by Singh et al., (2008), who found that the improvement technologies of mustard crop have significant effect in higher productivity of mustard. The findings revealed that a gap exists between the actual farmer's yield and realizable yield potential of the variety. Use of improved variety carry potential to enhance the present level of mustard productivity which is not percolating down at desired pace due to lack of confidence among the farmers. Hence, to exploit the potential of improved production and protection technologies efforts through CFLDs ought to be increased awareness among the farmers.

The extension gap showed an increasing trend. The extension gap ranging between 3.84-5.75q/ha during the study period emphasizes the need to educate the farmers through various means for adoption of improved agricultural technologies to reverse the trend. The trend of technology gap(ranging between 5.33 to $8.38 \mathrm{q} / \mathrm{ha}$ ) reflects the farmers cooperation in carrying out such demonstrations with encouraging results in subsequent years. The technology gap observed might be attributing to the dissimilarity in soil fertility status and weather conditions. Mukharjee(2003), have also opined that depending on identification and use of farming situation ,specific interventions may have greater implications in enhancing system productivity.
Similar findings were also recorded by Mitra et al., (2010).The technology index, showed the feasibility of the evolved technology at the farmer's field. The lower the value of technology index, the more is the feasibility of technology. The wider gap in technology index (ranging between 25.38-34.92\%) during the study period in certain region, may be attributed to the difference in soil fertility status, weather condition, non-availability of irrigations water and insect- pests attack in the crop.

The benefit cost ratio of front line demonstrations have been presented in Table 2 clearly showed higher $\mathrm{BC}$ ratio of recommended practices was than control plots i.e. farmers practices in all the years of study. The benefit cost ratio of demonstrated and control plots were2.83and 1.52,2.75 and2.00,2.56 and2.1.74,2.49 and 1.74, during 2017-18,2018-19,2019-20 respectively. Hence, favourable benefit cost ratios proved the economic viability of the interventions and convinced the farmers on the utility of interventions. Similar findings were reported by Sharma(2003) in moth bean and Gurumukhi and Mishra(2003) in sorghum. The result of Cluster Front Line Demonstrations convincingly brought out that the yield of rapeseed -mustard could be increased by $37.64 \%$ to $55.61 \%$ with the intervention of balanced nutrient coupled with the improved seed and disease management in the Darbhanga district of Bihar. From the above finding, it can also be concluded that use of scientific methods of mustard cultivation can reduced the technology gap to a considerable extent thus leading to increased productivity of the district. Moreover, extension agencies in the district need to provide proper technology support to the farmers through different educational and extension methods to reduce the extension gap for higher oilseed production in the Darbhanga district of Bihar. 


\section{References}

Chattopadhyay,C, Meena,PD,Sastry,RK and Meena,RL (2003) relationship among photological and agronomic attributes for soil borne diseases of three oilseed crops. Indian j. Pl Protec,31:127-128.

Choudhary,BN.1999.KrishiVigyan Kendra- A guide for KVK managers.Division of Agricultural Extension, ICAR.,pp 7378.

Gurumukhi,DR and Mishra Sumit.2003. Sorghum front line demonstration-A success story. Agriculture Extension Reviev, $15: 22-23$.

Katare, Subhash, Pandey, SK and Mustafa, Mohd.2011. Yield gap analysis of Rapeseed- mustard through front line demonstration. Agric Update6:5-6

Mehra,K.L(1968).History and ethio botany of mustardin India. Adv.Front.PlSci 19:57

Mitra and Samajdar,T (2010) Yield gap analysis of rapeseed-mustard through front line demonstration .Agri Extension Review; 22: 16-17.

Mitra, Biplab and Samajdar, T.2010. Yield gap analysis of rapeseed-mustard through Front Line Demonstration. Agric Exten Reviev,(April-June):16-17

Mukharjee N. 2003. Participatory Learning and Action. Concept Publishing Company, New Delhi India,pp 63-65.

Samui, SKMaitra, S Roy, DK,Mandal,AK and Saha,D.2000. Evaluation of Front Line Demonstration on groundnut. $J$ Indian Soc. Coastal Agric res, 18: 180183

Sen,Raja.2003.Hyola PAC-401:Benefit at its Best www.commodity India.com September 2003,pp-6-7.

Sharma, OP.2003. moth bean yield improvement through Front Line Demonstrations. Agric Ext Rev, 15 : 1113.

Singh, G, Sirohi, A and Malik, YP.2008. Impact of improved technology on the productivity of Indian mustard. $J$ Oilseeds Res, 25: 125.

Singh, SN, Singh, VK, Singh, RK and Singh, Rakesh K. 2007. Evaluation of on -farm front line demonstration on the yield mustard in Central Plain Zone of Uttar Pradesh. Indian Res J Ext Edu, 7: 79-81.

Tiwari,RB; Singh, Vinay and Parihar, P. 2003. Role of FLD in transfer of gram production technology. Maharastra $J$ Ext. Edu, 22: 139.

Tomer, L. S; Sharma, BP and Joshi, K. 2003. Impact of Front Line Demonstration of soybean in transfer of improved technology. $J$ Ext Edu, 22: 139.

Venkattakumar, $\quad$ R; $\quad$ RamanaRao,SV; Padmaiah,M and Madhuri,P.2010. Production constraints and information needs of growers in Andhra Pradesh. AgricExtn review,(April-June): 21-24.

\section{How to cite this article:}

Ram Prawesh Prasad, D. Shekhar, M. S. Kundu, A. P. Rakesh, Amba Kumari and Chandan Kumar. 2020. Yield gap Analysis of Rapeseed- Mustard through Cluster Front Line Demonstrations in Darbhanga District of Bihar, India. Int.J.Curr.Microbiol.App.Sci. 9(06): 170-175. doi: https://doi.org/10.20546/ijcmas.2020.906.022 